\title{
Anti-allergic and anti-inflammatory effects of butanol extract from Arctium Lappa L
}

\author{
Eun-Hwa Sohn' ${ }^{1}$, Seon-A Jang ${ }^{1}$, Haemi Joo ${ }^{2}$, Sulkyoung Park', Se-Chan Kang ${ }^{3}$, Chul-Hoon Lee ${ }^{4}$, Sun-Young Kim ${ }^{5^{*}}$
}

\begin{abstract}
Background: Atopic dermatitis is a chronic, allergic inflammatory skin disease that is accompanied by markedly increased levels of inflammatory cells, including eosinophils, mast cells, and T cells. Arctium lappa L. is a traditional medicine in Asia. This study examined whether a butanol extract of A. lappa (ALBE) had previously unreported antiallergic or anti-inflammatory effects.

Methods: This study examined the effect of ALBE on the release of $\beta$-hexosaminidase in antigen-stimulated-RBL$2 \mathrm{H} 3$ cells. We also evaluated the ConA-induced expression of IL-4, IL-5, mitogen-activated protein kinases (MAPKs), and nuclear factor (NF)- $\kappa$ B using RT-PCR, Western blotting, and ELISA in mouse splenocytes after ALBE treatment.

Results: We observed significant inhibition of $\beta$-hexosaminidase release in RBL-2H3 cells and suppressed mRNA expression and protein secretion of IL-4 and IL-5 induced by ConA-treated primary murine splenocytes after ALBE treatment. Additionally, ALBE $(100 \mu \mathrm{g} / \mathrm{mL})$ suppressed not only the transcriptional activation of NF- $\kappa$ B, but also the phosphorylation of MAPKs in ConA-treated primary splenocytes.

Conclusions: These results suggest that ALBE inhibits the expression of IL-4 and IL-5 by downregulating MAPKs and $\mathrm{NF}-\kappa \mathrm{B}$ activation in ConA-treated splenocytes and supports the hypothesis that ALBE may have beneficial effects in the treatment of allergic diseases, including atopic dermatitis.
\end{abstract}

\section{Background}

Atopic dermatitis is a chronic, allergic inflammatory skin disorder characterized by pruritic chronic eczema, elevated serum IgE levels, and massive cellular infiltrates, including eosinophils, mast cells, and lymphocytes [1,2]. Because mast cells play essential roles in provoking the pathogenesis of allergic reactions via the degranulation process, measuring the degree of degranulation reflects the level of mast cell activation. $\beta$-Hexosaminidase released by these cells during this process has been reported to be a suitable marker for determining the degree of degranulation [3]. After an allergen triggers the allergic reactions, allergic mediators, including histamine, cytokines, and arachidonic acid derivatives, provoke acute and chronic allergic inflammation responses $[4,5]$. Various cells involved in the allergic reaction infiltrate the lesion. Among these, T helper 2 (Th2) cells are the most important cell type involved in atopic dermatitis

\footnotetext{
*Correspondence: nel1205@hanmail.net

${ }^{5}$ Department of Pediatrics, College of Medicine, Hanyang University, Seoul, 133-792, Korea

Full list of author information is available at the end of the article
}

development. Th2 cells release cytokines, such as IL-4, IL-5, and IL-13, in allergic inflammation and atopic dermatitis. The cytokines released by Th2 cells lead to the proliferation and activation of both mast cells and eosinophils in atopic and allergic skin inflammation, consequently leading to pruritus and impaired skin barrier function [6]. In particular, IL-4 contributes to the expansion of the Th2 cell subset from naïve $\mathrm{T}$ cells and the isotype switching of B cells to produce IgE against specific environmental allergens [7]. Cytokines, such as IL-4 and IL-5, are representative markers of the allergic reaction, based on their roles against allergens.

Arctium lappa $L$. is a popular edible vegetable cultivated in many countries. The roots are widely used in food, whereas the seeds are used in traditional medicine as diuretic, antipyretic, or detoxifying agents [8]. There are reports that A. lappa has anti-inflammatory [9], free radical scavenging [10], and antioxidant [11] activities, and that components [12] also have desmutagenic [13] and hepatoprotective [14] effects. Although A. lappa and its components have these biological activities, no reported study has evaluated the anti-allergic or anti-inflammatory

\section{() Biomed Central}


effects of A. lappa root in atopic dermatitis or the molecular mechanisms involved. We examined the butanol extract of A. lappa (ALBE) roots because it significantly inhibited antigen-induced $\beta$-hexosaminidase release. Atopic dermatitis is a chronic, allergic inflammatory skin disorder, and we investigated both the anti-allergic and anti-inflammatory effects of ALBE. We examined the anti-allergic effects by checking the release of $\beta$-hexosaminidase induced by dinitrophenyl (DNP)-BSA in RBL-2H3 mast cells and expression levels of IL-4 and IL-5 in primary splenocytes after treatment with concanavalin A (ConA), which generates Th2 cytokines as in an allergic environment. We also examined the translocation of NF- $\kappa \mathrm{B}$ and the phosphorylation of MAPKs, which are activated during inflammation, in ConA-treated primary murine splenocytes to validate the anti-inflammatory effects of ALBE.

\section{Methods}

\section{Preparation of extract}

Roots of Arctium lappa L. (1 kg) were extracted with $30 \%$ ethanol under reflux ( $10 \mathrm{~L}, 24 \mathrm{~h}$, twice). The extract solutions were filtered and then evaporated at $40^{\circ} \mathrm{C}$ under reduced pressure, yielding $88.8 \mathrm{~g}$ of dry powder. Approximately $50 \mathrm{~g}$ of the ethanol extract were resuspended in $1 \mathrm{~L}$ of water and then partitioned with equal volumes of $n$-hexane, $\mathrm{AcOEt}$, and $\mathrm{n}-\mathrm{BuOH}$ to give n-hexane, AcOEt, n-BuOH, and $\mathrm{H}_{2} \mathrm{O}$ fractions. The butanolic fraction weighed $22.0 \mathrm{~g}$ and the sample was named A. lappa butanolic extract (ALBE).

\section{Cell culture and experimental animals}

The RBL-2H3 rat mast cell line was obtained from the American Type Culture Collection (Rockville, MD, USA) and grown in minimum essential medium (MEM) with 15\% fetal bovine serum (FBS), $2 \mathrm{mM} \mathrm{L}$-glutamine, $100 \mathrm{U} / \mathrm{mL}$ penicillin, and $100 \mu \mathrm{g} / \mathrm{mL}$ streptomycin at $37^{\circ} \mathrm{C}$ in a humidified incubator with a $5 \% \mathrm{CO}_{2} / 95 \%$ air atmosphere. Specific-pathogen-free 8-10-week-old male C57BL/6 mice were purchased from Orient Bio (Gyeonggi-do, Korea) and housed in an animal room at a temperature of $23 \pm 1^{\circ} \mathrm{C}$ and a humidity of $55 \pm 5 \%$, with a 12/12-h light/dark cycle. The mice were fed a standard laboratory diet with tap water ad libitum.

Animal care and all experimental protocols were performed following the Institute for Laboratory Animal Research (ILAR) guidelines.

\section{Materials}

The anti-dinitrophenyl (DNP)-IgE and 4-nitrophenyl $\mathrm{N}$-acetyl- $\beta$-D-glucosaminide were from Sigma-Aldrich, DNP-bovine serum albumin (BSA) was from Biosearch Technologies, minimum essential medium was from Invitrogen, fetal bovine serum (FBS) was from WelGENE, enzyme immunoassay reagents for cytokine assays, such as IL-4 and IL-5, were from BD Biosciences, the protein assay kit was from Bio-Rad Laboratories, anti-pERK, antiERK, anti-pJNK, anti-JNK, and anti-p-p38 were from Cell Signaling Technology, anti-p65 and anti-p38 were from Santa Cruz Biotechnology, anti- $\beta$-actin was from SigmaAldrich, anti- $\alpha$-tubulin was from Abfrontier, the ECL chemiluminescence system was from GE Healthcare, and the polyvinylidene difluoride (PVDF) membrane was from Millipore. The polymerase chain reaction (PCR) oligonucleotide primers were custom synthesized by Bionics (Korea).

\section{XTT assay for cell cytotoxicity and proliferation}

Splenocyte cytotoxicity and proliferation were examined using the XTT assay kit, according to the manufacturer's instructions. The spleen was removed aseptically and dissociated into a single cell suspension in culture medium. Cells $\left(5 \times 10^{5}\right.$ cells/well) were incubated with various ALBE concentrations $(1,10,100 \mu \mathrm{g} / \mathrm{mL})$ in the presence or absence of ConA at $3 \mu \mathrm{g} / \mathrm{mL}$ for T cell activation. After incubating the cells for $72 \mathrm{~h}$, a mixture of $25 \mu \mathrm{L}$ of phenazine methosulfate (PMS; electron-coupling reagent) and $25 \mu \mathrm{L}$ of XTT [2,3-bis(2-methoxy-4-nitro-5-sulfophenyl)$2 \mathrm{H}$-tetrazolium-5-carboxanilide] was added to each well. The cells were further incubated for $4 \mathrm{~h}$ to allow XTT formazan production. The absorbance was determined with a microplate reader at a test wavelength of $450 \mathrm{~nm}$ and a reference wavelength of $690 \mathrm{~nm}$.

\section{$\beta$-Hexosaminidase release assay}

Degranulation of RBL-2H3 cells was evaluated by measuring the activity of the granule-stored enzyme- $\beta$ hexosaminidase secreted in the extracellular medium. Cells were cultured in 24 -well plates $\left(2 \times 10^{5}\right.$ cells/ well) overnight. The cells were sensitized with antiDNP-IgE $(100 \mathrm{ng} / \mathrm{mL})$ for $16 \mathrm{~h}$ at $37^{\circ} \mathrm{C}$. After washing the cells with TGCM buffer $(136 \mathrm{mM} \mathrm{NaCl}, 2.68 \mathrm{mM}$ $\mathrm{KCl}, 0.36 \mathrm{mM} \mathrm{NaH} \mathrm{PO}_{2} \mathrm{H}_{2} \mathrm{O}, 1 \mathrm{mM} \mathrm{CaCl}, 0.5 \mathrm{mM}$ $\mathrm{MgCl}_{2}, 11.9 \mathrm{mM} \mathrm{NaHCO} 3,5 \mathrm{mM}$ dextrose, $1 \mathrm{~g} / \mathrm{L}$ gelatin, $\mathrm{pH}$ 7.4), they were pretreated with $\operatorname{ALBE}(1,10$, $100 \mu \mathrm{g} / \mathrm{mL}$ ) for $30 \mathrm{~min}$ and then treated with DNPBSA $(1 \mu \mathrm{g} / \mathrm{mL})$ for $30 \mathrm{~min}$ at $37^{\circ} \mathrm{C}$. Aliquots of the cellular supernatant $(15 \mu \mathrm{L})$ were transferred to 96 -well plates and incubated with $60 \mu \mathrm{L}$ of substrate $(1 \mathrm{mM}$ $p$-nitrophenyl- $\mathrm{N}$-acetyl- $\beta$ - $\mathrm{D}$-glucosaminide in citrate $0.05 \mathrm{M}, \mathrm{pH} 4.5$ ) for $60 \mathrm{~min}$ at $37^{\circ} \mathrm{C}$. The cells were lysed with $0.1 \%$ Triton $\mathrm{X}-100$ before removing the supernatant to measure the total $\beta$-hexosaminidase activity. The reaction was stopped by adding $150 \mu \mathrm{L}$ of $\mathrm{Na}_{2} \mathrm{CO}_{3}-\mathrm{NaHCO}_{3}$ buffer $0.1 \mathrm{M}, \mathrm{pH}$ 10. The absorbance at $405 \mathrm{~nm}$ was measured with a microplate reader (Themo Labsystems). The results were presented as the percentage of total $\beta$-hexosaminidase 
content of the cells determined by cell lysis with $0.1 \%$ Triton X-100.

$$
\% \text { Degranulation }=\mathrm{OD}_{\text {supernatant }} /\left(\mathrm{OD}_{\text {supernatant }}+\mathrm{OD}_{\text {triton } \mathrm{x}-100}\right) \times 100
$$

\section{NA preparation and mRNA analysis by RT-PCR}

Total splenocytes were plated at $3 \times 10^{7}$ cells $/ \mathrm{mL}$ and treated with ALBE $(100 \mu \mathrm{g} / \mathrm{mL})$ and ConA $(3 \mu \mathrm{g} / \mathrm{mL})$ for $16 \mathrm{~h}$. Total RNA from the treated cells was prepared with the TRIzol Reagent (Invitrogen), according to the manufacturer's protocol, and stored at $-70^{\circ} \mathrm{C}$ until use. For detecting cytokines, including IL-4 and IL-5, total RNA was extracted after stimulation and treatment. The sequences of the primers used in this study were: IL-4 forward, 5'-ATG GGT CTC AAC CCC CAG CTA GT3'; IL-4 reverse, 5'-GCT CTT TAG GCT TTC CAG GAA GTC-3'; IL-5 forward, 5'-AGC ACA GTG GTG AAA GAG ACC TT-3'; IL-5 reverse, 5'-TCC AAT GCA TAG CTG GTG ATT T-3'; GAPDH forward, 5'-GTG GCA AAG TGG AGA TTG TTG CC -3', and GAPDH reverse, 5'-GAT GAT GAC CCG TTT GGC TCC-3'. Each transcript was quantified as described in the instrument manual and normalized to the amount of GAPDH, a housekeeping gene.

\section{Measurement of cytokine production (IL-4 and IL-5 secretion)}

For cytokine immunoassays, total splenocytes were plated at $3 \times 10^{7}$ cells $/ \mathrm{mL}$ and treated with ALBE $(100 \mu \mathrm{g} /$ $\mathrm{mL})$ and ConA $(3 \mu \mathrm{g} / \mathrm{mL})$ for $16 \mathrm{~h}$. Culture supernatants were collected and the amount of secreted IL-4 and IL-5 was measured using an enzyme-linked immunosorbent assay (ELISA) using the protocol supplied by BD Biosciences.

\section{Subcellular fractionation}

Cytosolic and nuclear extracts were prepared. In brief, splenocytes $\left(5 \times 10^{7}\right.$ cells $\left./ \mathrm{mL}\right)$ were plated into $100-\mathrm{mm}$ dishes and treated with ALBE $(100 \mu \mathrm{g} / \mathrm{mL})$ and ConA ( $3 \mu \mathrm{g} / \mathrm{mL}$ ) for $4 \mathrm{~h}$. The harvested cells were resuspended in $0.2 \mathrm{ml}$ of buffer A (10 mM HEPES at pH 7.5, $1.5 \mathrm{mM}$ $\mathrm{MgCl}_{2}, 10 \mathrm{mM} \mathrm{KCl}, 1 \mathrm{mM}$ DDT, 0.1\% NP-40, $0.2 \mathrm{mM}$ PMSF). The cells were lysed on ice for $15 \mathrm{~min}$, and centrifuged $\left(5,000 \mathrm{~g}, 5 \mathrm{~min}, 4^{\circ} \mathrm{C}\right)$. The supernatant was collected as cytosolic extracts. The nucleic pellet was washed with buffer A lacking NP-40, and resuspended in $0.025 \mathrm{ml}$ of buffer C (20 mM HEPES, pH 7.5, 25\% glycerol, $0.42 \mathrm{M} \mathrm{NaCl}, 0.2 \mathrm{mM}$ EDTA, $1.5 \mathrm{mM} \mathrm{MgCl}_{2}$, $1 \mathrm{mM}$ DDT, $0.2 \mathrm{mM}$ PMSF). After incubation on ice for $30 \mathrm{~min}$, nuclear debris was spun down $(13,000 \mathrm{~g}$, $10 \mathrm{~min}, 4^{\circ} \mathrm{C}$ ). The supernatant was collected as nuclear extracts. The protein concentration was measured using a protein assay kit (Bio-Rad).

\section{Western blotting}

Total splenocytes were plated at $3 \times 10^{7}$ cells $/ \mathrm{mL}$ and treated with ALBE $(100 \mu \mathrm{g} / \mathrm{mL})$ and ConA $(3 \mu \mathrm{g} / \mathrm{mL})$ for $15 \mathrm{~min}$ and then harvested and lysed in a lysis buffer containing $20 \mathrm{mM}$ Tris, pH 7.6, $150 \mathrm{mM} \mathrm{NaCl}$, and 1\% Triton X-100 with a protease inhibitor cocktail. Protein contents were measured using a protein assay kit (BioRad). Samples were diluted with $1 \times$ lysis buffer containing $1 \% \beta$-mercaptoethanol. Equal amounts of cellular protein $(50 \mu \mathrm{g})$ were resolved by $10 \%$ SDS-PAGE and transferred onto nitrocellulose membranes. After blocking, membranes were incubated with the target antibody and then with horseradish peroxidase-conjugated secondary antibody to IgG. Immunoreactive proteins were visualized using the ECL Western blot detection system. The protein level was compared to a loading control, such as $\beta$-actin or non-phosphorylated protein.

\section{Statistical analyses}

Each experiment was repeated three or four times, and the results of a representative experiment are shown. The results are expressed as the means \pm SEM and were compared using Student's $t$-test. A statistical probability of $p<0.05$ was considered significant (\# $p<0.05$, \#\# $p<0.01,{ }^{*} p<0.05$, and $\left.{ }^{* *} p<0.01\right)$.

\section{Results}

ALBE inhibits antigen-induced $\beta$-hexosaminidase release in IgE-sensitized mast cells

Rat mast cell line RBL-2H3 cells were used to determine the effect of ALBE on the secretion of $\beta$-hexosaminidase. Initially, we measured the cytotoxicity of ALBE on RBL-2H3 cells using the XTT assay. ALBE at concentrations ranging from $1-100 \mu \mathrm{g} / \mathrm{mL}$ did not significantly affect the cytotoxicity in $24 \mathrm{~h}$ (Figure 1A). Thus, we treated DNP-IgE-sensitized RBL-2H3 cells with ALBE ranging from $1-100 \mu \mathrm{g} / \mathrm{mL}$ in subsequent experiments. ALBE significantly suppressed the DNP-BSA induced $\beta$-hexosaminidase secretion in IgE-sensitized RBL-2H3 cells at 1,10 , and $100 \mu \mathrm{g} / \mathrm{mL}$ and the effects are dosedependent (Figure 1B). Ketotifen fumarate, an antiallergic drug, also decreased the $\beta$-hexosaminidase secretion. The results showed that ALBE significantly inhibited antigen-induced mast cell degranulation.

\section{Effects of ALBE on cell proliferation and cytokine (IL-4, IL-5)} secretion in ConA-induced primary murine splenocytes We examined the effects of ALBE on ConA-induced $\mathrm{T}$ cell proliferation in primary murine splenocytes for $72 \mathrm{~h}$ to examine the immunomodulatory effect of ALBE. The concentration and duration of ALBE treatment without ConA had no effect on splenocyte viability (data not shown). As shown in Figure 2, ALBE significantly increased splenocyte proliferation in ConA-treated cells 
A.

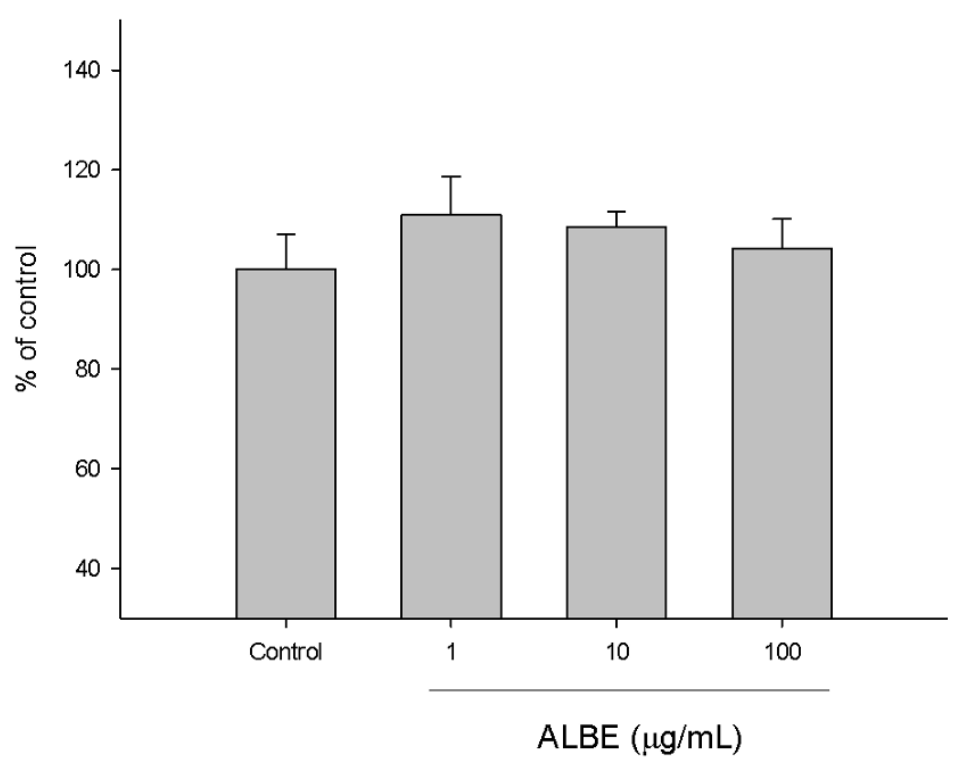

B.

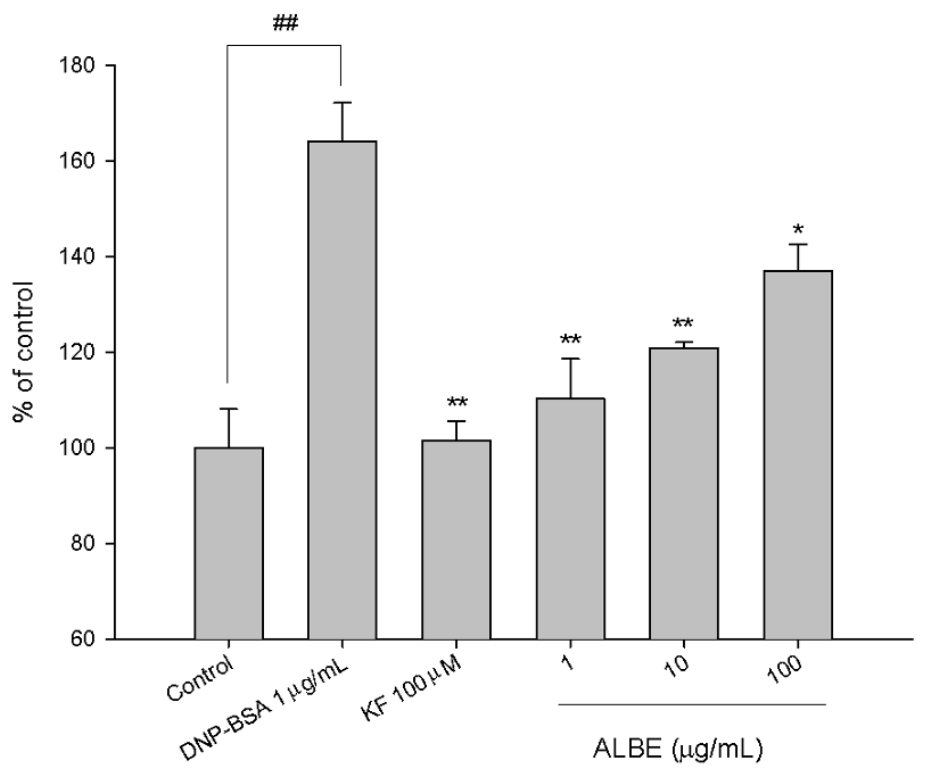

Figure 1 Effects of ALBE on cell viability and antigen-induced $\beta$-hexosaminidase in RBL-2H3 cells. (A) The cells were treated with various concentration of ALBE for $24 \mathrm{~h}$. Cell viability was assessed using XTT assay. Absorbance was measure data at $450 \mathrm{~nm}$ and $650 \mathrm{~nm}$. (B) The cells were sensitized by overnight incubation with $1 \mathrm{\mu g} / \mathrm{ml}$ of DNP-specific IgE in medium. This DNP-lgE-sensitized RBL-2H3 cells were pre-incubated with various concentration of ALBE for $30 \mathrm{~min}$ and then incubated with antigen (DNP-BSA) for $15 \mathrm{~min}$ in order to measure the release of $\beta$-hexosaminidase. Each bar shows the means \pm SEM of four independent experiments. ${ }^{\# \#} \mathrm{P}<0.01$ : significantly different from control group ${ }^{* * P}<0.01,{ }^{*} \mathrm{P}<0.05$ : significantly different from DNP-BSA alone. KF; ketotifen fumarate. 


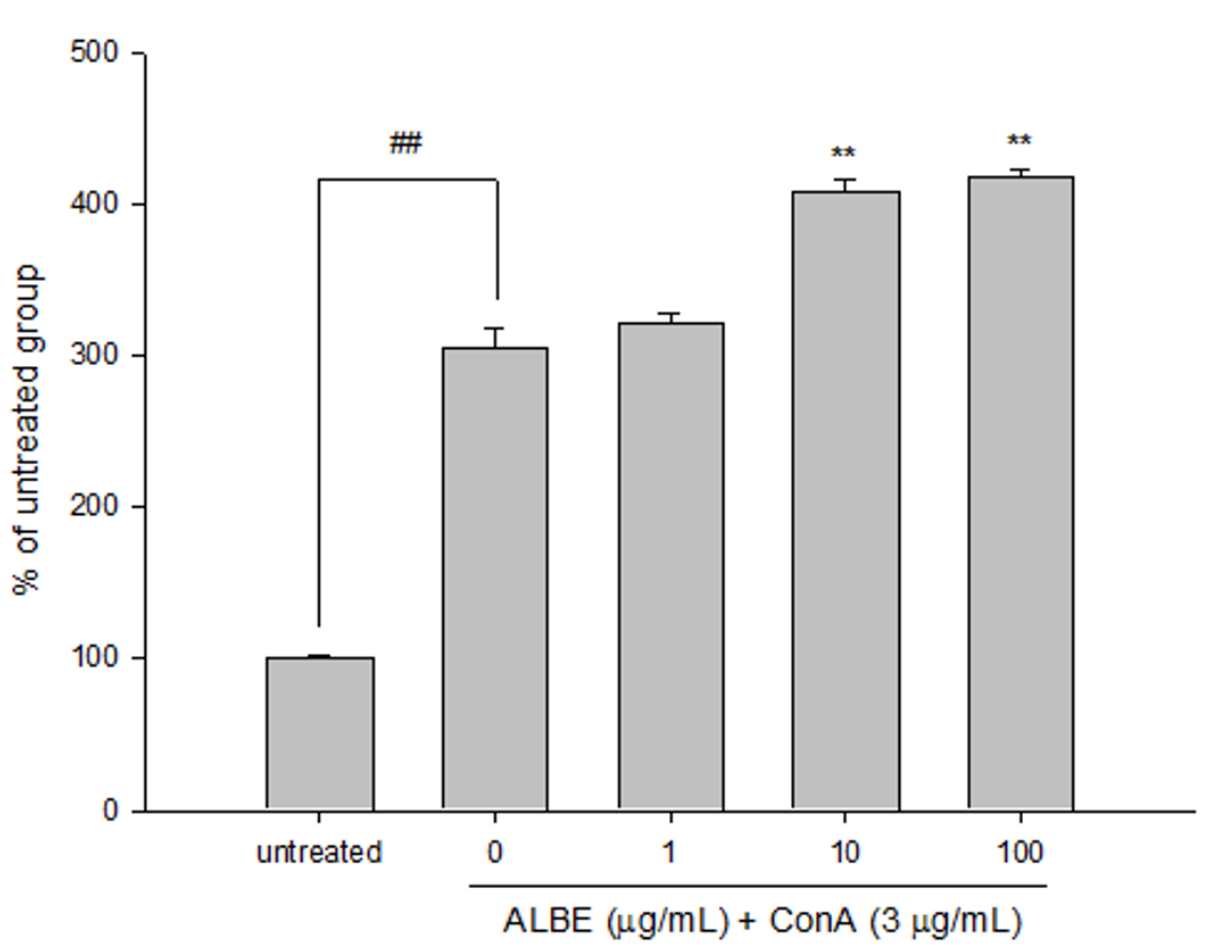

Figure 2 Effects of ALBE on the proliferation of ConA-induced primary murine splenocytes. Splenocytes were treated with various concentrations of ALBE and ConA ( $3 \mu \mathrm{g} / \mathrm{ml})$ for $72 \mathrm{~h}$. Cell proliferation was assessed using XTT assays. Absorbance was measure data at $450 \mathrm{~nm}$ and $650 \mathrm{~nm}$. Each bar shows the means \pm SEM of four independent experiments. ${ }^{\# \# P}<0.01$ : significantly different from the untreated group. ${ }^{*} \mathrm{P}<0.01$ : significantly different from the ConA alone group.

at 10 and $100 \mu \mathrm{g} / \mathrm{mL}(p<0.05)$. Additionally, we examined the effects of ALBE on the expression and secretion of Th2 cytokines, such as IL-4 and IL-5, in primary murine splenocytes using RT-PCR and ELISA assays to investigate the further involvement of ALBE in Th2 functions in the atopic dermatitis-like skin lesions. ConA-induced IL-4 and IL- 5 secretion was suppressed by ALBE treatment in splenocytes (Figure 3, Figure 4). ALBE treatment without ConA had no effect on IL-4 or IL-5 mRNA expression (data not shown), whereas ALBE with ConA significantly decreased the mRNA expression of IL-4 (to $55.3 \%$ ) and IL-5 (to $29.0 \%$ ) at $100 \mu \mathrm{g} / \mathrm{mL}$, compared with ConA-stimulated splenocytes (Figure 3A, Figure 4A). In agreement with the RT-PCR results, ALBE inhibited the protein secretion of IL-4 (to 13.6\%) and IL-5 (to 10.8\%) under the same conditions (Figure 3B, Figure 4B). These results suggest that ALBE had immunostimulatory effects on $T$ cells and meaningfully inhibited the antigeninduced mRNA expression and production of cytokines related to allergic and atopic reactions.

Effects of ALBE on NF- $\kappa$ B activation and phosphorylation of MAPKs in ConA-induced primary murine splenocytes Increased expression of NF- $\kappa \mathrm{B}$ (p65) was observed in the nucleus after treatment with ALBE plus ConA for
$4 \mathrm{~h}$ (Figure 5). The relative intensity of NF- $\kappa \mathrm{B}$ (p65) translocation in the nucleus was increased to $6.3 \%$ in the presence of ConA compared with the absence of ConA in the control. In contrast, the relative intensity of NF- $\kappa \mathrm{B}$ (p65) translocation in the nucleus was decreased considerably, to $8.7 \%$, after the addition of $100 \mu \mathrm{g} / \mathrm{mL}$ ALBE in the presence of ConA compared with ConA treatment alone. These data demonstrate that ALBE attenuated NF- $\kappa$ B activation and might affect downstream IL-4 and IL-5 production. ALBE inhibits ConA-induced phosphorylation of MAP kinases such as p38, JNK, and ERK (Figure 6). We found that ALBE attenuated not only the ConA-induced increase in the activity of NF- $\kappa \mathrm{B}$, but also the phosphorylation of MAPKs and these results suggest that ALBE may prevent allergic and atopic inflammation via NF- $\kappa \mathrm{B}$ and the MAPKs signaling pathway.

\section{Discussion}

Traditional medicines isolated from natural products often have positive effects in the prevention and healing of various immune disorders, such as allergy and atopic inflammation. In this study, the butanol fraction of Arctium lappa L. showed potential anti-allergic and antiinflammatory effects by decreasing $\beta$-hexosaminidase 
A.
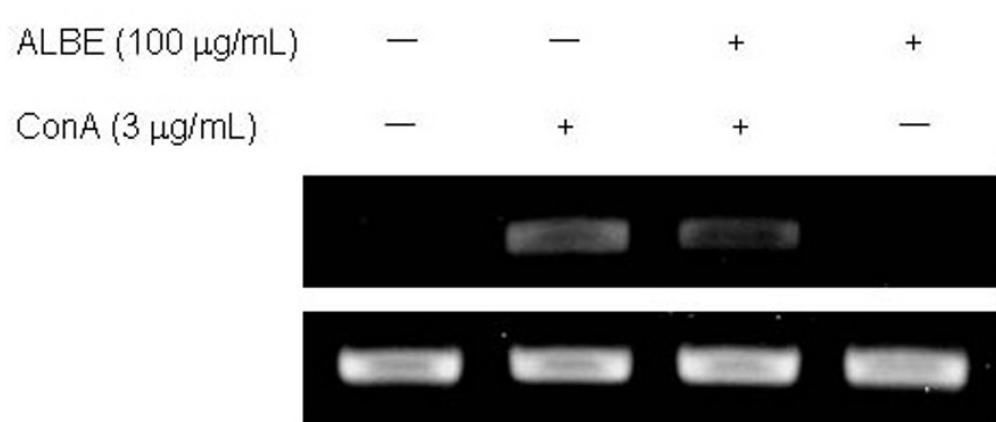

GAPDH

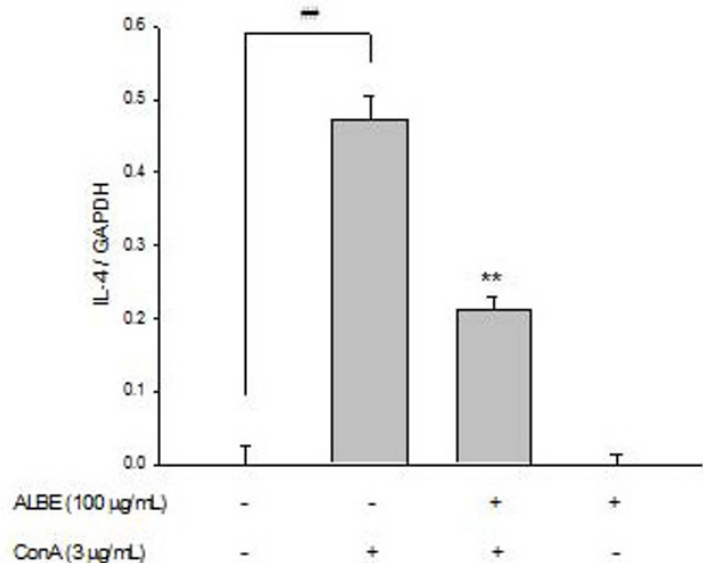

B.

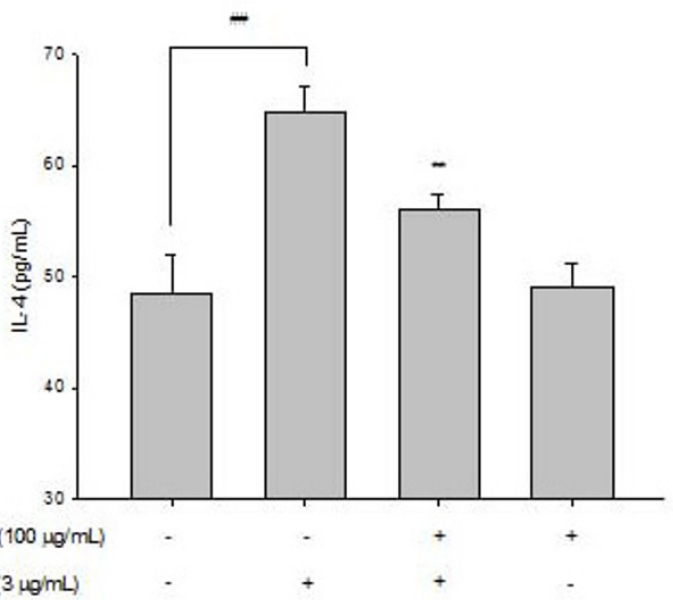

Figure 3 The mRNA expressions and protein secretions of IL-4 by ALBE in primary murine splenocytes. (A) The effects of ALBE on the mRNA expression of IL-4. ALBE $(100 \mu \mathrm{g} / \mathrm{ml})$ were treated to splenocytes with or without ConA $(3 \mu \mathrm{g} / \mathrm{ml})$ for $16 \mathrm{~h}$. The mRNA expression of IL-4 was assessed by RT-PCR described in method. Each bar shows the means \pm SEM of three independent experiments. (B) The effects of ALBE on the protein secretion of IL-4. ALBE $(100 \mu \mathrm{g} / \mathrm{ml})$ were treated to splenocytes with or without ConA $(3 \mu \mathrm{g} / \mathrm{ml})$ for $16 \mathrm{~h}$. The protein secretion of IL-4 was assessed by ELISA described in methods. Each bar shows the means \pm SEM of four independent experiments. ${ }^{\# \#} \mathrm{P}<0.01$ : significantly different from the untreated group. ${ }^{* *} \mathrm{P}<0.01$ : significantly different from the ConA alone group. 
A.

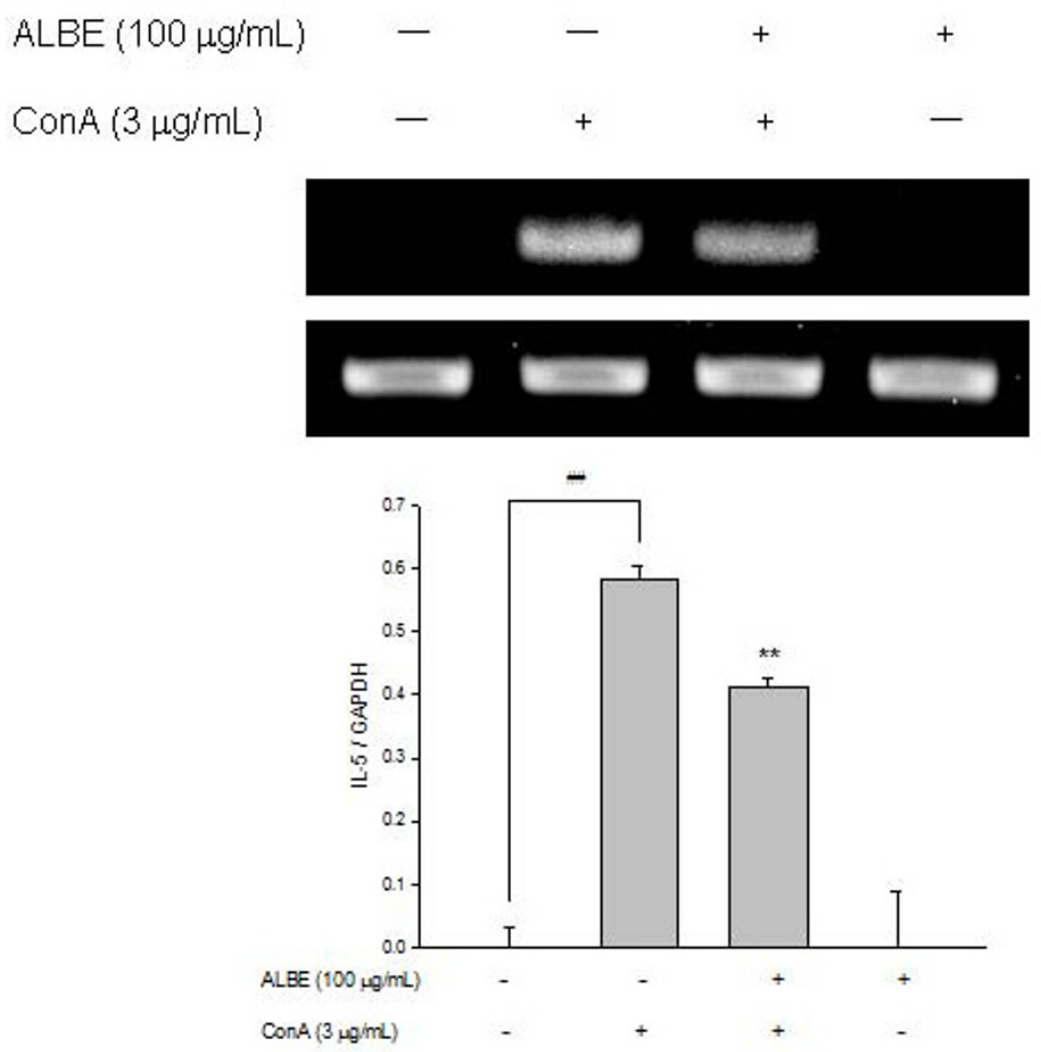

IL-5

GAPDH

B.

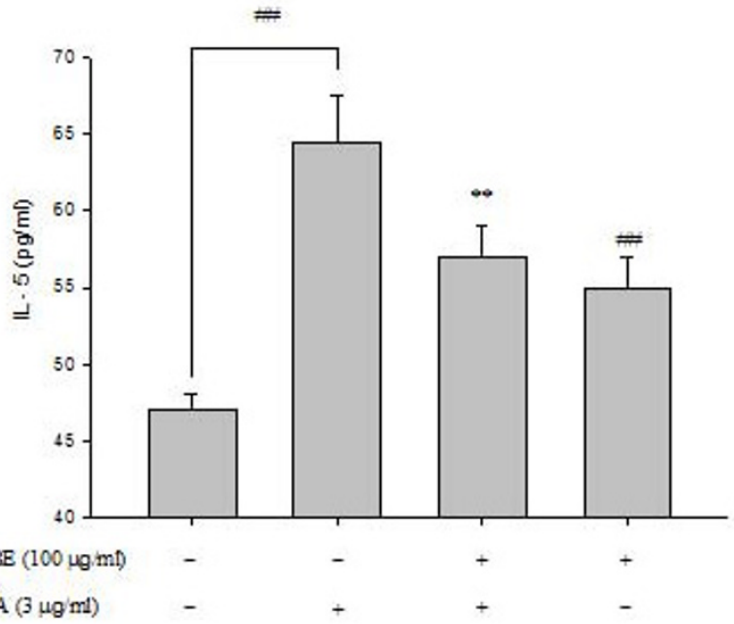

Figure 4 The mRNA expressions and protein secretion of IL-5 by ALBE in primary murine splenocytes. (A) The effects of ALBE on the mRNA expression of IL-5. ALBE $(100 \mu \mathrm{g} / \mathrm{ml})$ were treated to splenocytes with or without ConA $(3 \mu \mathrm{g} / \mathrm{ml})$ for $16 \mathrm{~h}$. The mRNA expression of IL-5 was assessed by RT-PCR described in method. Each bar shows the means \pm SEM of three independent experiments. (B) The effects of ALBE on the protein secretion of IL-5. ALBE $(100 \mu \mathrm{g} / \mathrm{ml})$ were treated to splenocytes with or without ConA $(3 \mu \mathrm{g} / \mathrm{ml})$ for $16 \mathrm{~h}$. The protein secretion of IL-5 was assessed by ELISA described in methods. Each bar shows the means \pm SEM of four independent experiments. ${ }^{\# \#} \mathrm{P}<0.01$ : significantly different from the untreated group. ${ }^{*} \mathrm{P}<0.01$ : significantly different from the ConA alone group. 

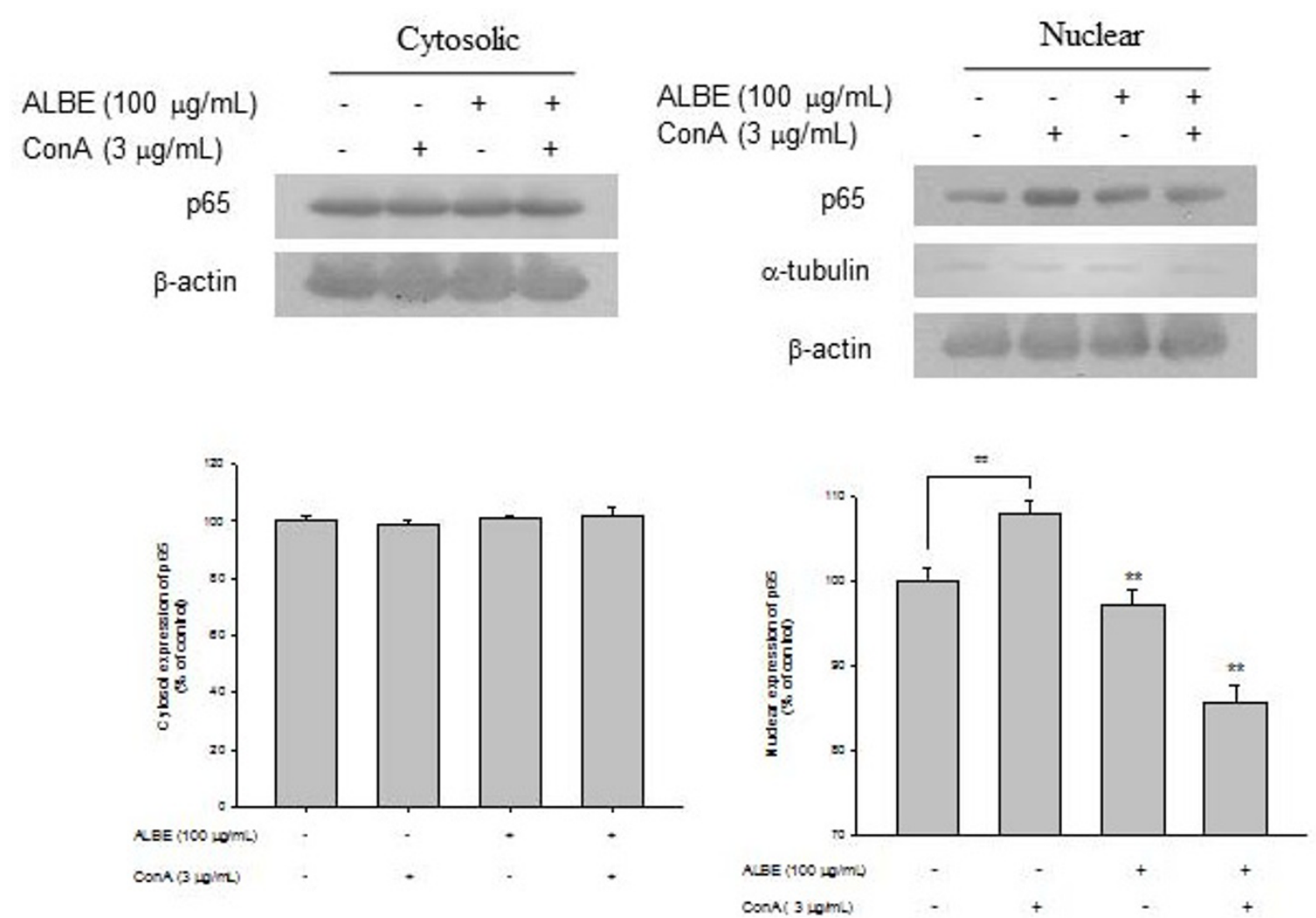

Figure 5 Effects of ALBE on NF- $\kappa$ B activation in ConA-induced primary murine splenocytes. ALBE (100 $\mu \mathrm{g} / \mathrm{ml})$ were treated to splenocytes with or without ConA ( $3 \mu \mathrm{g} / \mathrm{ml}$ ) for $15 \mathrm{~min}$. After isolation of cytosolic and nuclear fraction, the translocation of NF- $\kappa \mathrm{B}$ (p65) was assessed by Western blotting described in methods respectively. ${ }^{\# \#} P<0.01$ : significantly different from the untreated group. ${ }^{*} \mathrm{P}<0.01$ : significantly different from the ConA alone group.

release in mast cells and the secretion of IL-4 and IL-5 in ConA-induced T cells. Mast cells are primary effector cells involved in the allergic or immediate hypersensitivity responses [15]. The antigen crosslinking of the IgEFceRI complexes through the aggregation of IgE and FceRI on mast cells results in the release of $\beta$-hexosaminidase, which is a marker of mast cell degranulation. The release of $\beta$-hexosaminidase and histamines also causes the production of proinflammatory cytokines, such as IL-4, IL-6, and TNF- $\alpha$, which can potentiate inflammatory immune responses through the subsequent induction of other atopic inflammatory mediators. Thus, the modulation of cytokines in this process is considered a rational approach for regulating the early phase of allergic responses [5,15].

Atopic dermatitis is characterized by allergic skin inflammation. Pathological changes in atopic skin are observed as epidermal thickening and marked infiltration of inflammatory cells [16]. Atopic dermatitis has been associated with the Th2 phenotype and dominance of IL-4, IL-5, and IL-13 secretion $[17,18]$. We examined the inhibitory effects of ALBE on ConA-induced proliferation and cytokine (IL-4 and IL-5) secretion of splenocytes, which were used as a marker of Th2 lymphocyte function, to characterize the $\mathrm{T}$ cell immunomodulatory profile of ALBE. ALBE increased the ConA-induced proliferation and inhibitory effects on cytokine (IL-4 and IL-5) secretion in primary murine splenocytes. ALBE suppressed allergic-related Th2 function by decreasing the release of IL-4 and IL-5. However, it increased the total number of $\mathrm{T}$ cell subsets (Th1/Th2), indicating that it might decrease allergic-related Th2 cell function in some way without suppressing the immune system because it can augment all $\mathrm{T}$ cell subsets.

IL-4 acts as an eosinophil chemoattractant, which makes endothelial cells produce eosinophil chemotactic factor and eotaxin [19]. IL-4 is also essential in IgE production [20] and the switch from naïve $T$ cells to allergic Th2 cells [21]. An immunohistochemical examination of the skin lesions in $\mathrm{NC} / \mathrm{Nga}$ atopic model mice revealed the typical features of affected skin observed in patients with atopic dermatitis, such as increased infiltration of 


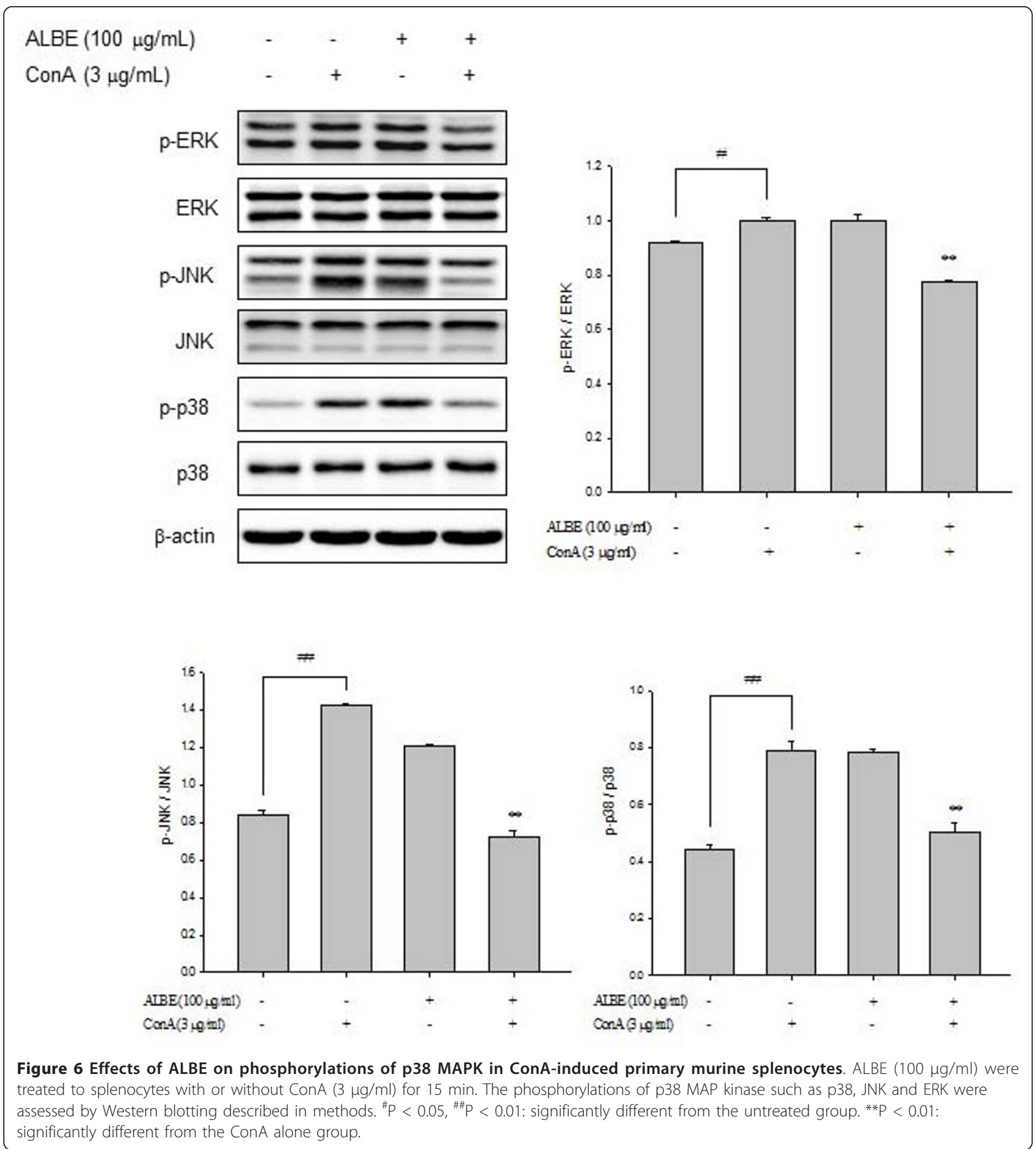

T cells, mast cells, and substantial expression of IL- 4 and IL-5 [22,23]. That ALBE can decrease the secretion of IL- 4 and IL- 5 released by ConA-induced Th2 cells indicates that it might have a useful effect in allergic and atopic inflammation. We subsequently evaluated the related mechanisms of ALBE on cytokine secretion, including $\mathrm{NF}-\kappa \mathrm{B}$ activation and the phosphorylation of MAPKs.
$\mathrm{NF}-\kappa \mathrm{B}$ is a key transcription factor that regulates the expression of genes involved in immune and inflammatory responses that require inflammatory cytokine production. NF- $\kappa$ B translocation and the MAPKs pathway are regarded as important processes in the regulation of the innate and acquired immune responses and chronic inflammation $[24,25]$. NF- $\kappa \mathrm{B}$ is also a critical transcription 
factor that regulates Th2 cell differentiation and Th2dependent airway inflammation [26].

We detected the inhibitory effects of ALBE on ConAinduced nuclear translocation of NF- $\kappa \mathrm{B}$ (p65). Increased $\mathrm{NF}-\kappa \mathrm{B}$ activity has been reported in asthma, an allergic disease, and the inhibition of NF- $\kappa \mathrm{B}$ activity decreased asthma [25]. Thus, we suggest that ALBE could have an anti-allergic effect based on the decrease in activated NF- $\kappa$ B it causes. Conventional MAP kinases are classified into three families: the c-Jun $\mathrm{N}$-terminal kinases (JNKs), the p38 MAP kinases, and the extracellular signal-regulated kinases (ERKs). Intracellular signal transduction, including the phosphorylation of p38 MAPK, is subsequently followed by NF- $\kappa$ B translocation, leading to the production of cytokines and chemokines. We also showed that ALBE significantly suppressed the ConAactivated phosphorylation of p38 MAPK in primary murine splenocytes. It has been reported that p38 MAPK activation can activate transcription factors that result in the expression of IL-4, IL-5, and IL-13 in human $\mathrm{T}$ cells in response to antigen exposure in allergic disease [25]. The fact that ALBE decreased ConAactivated MAPKs and mRNA expression of IL-4 and IL- 5 supports the possibility that ALBE may have antiallergic and anti-inflammatory effects.

\section{Conclusions}

ALBE may exert anti-allergic and anti-inflammatory activities by suppressing the transcription of NF- $\kappa$ B and the activated MAPKs signal pathway in splenocytes. Additionally, ALBE inhibited the antigen-induced degranulation of mast cells, as determined by the decreased release of $\beta$-hexosaminidase. From these results, we suggest that ALBE might be useful as a therapeutic agent for treating various forms of allergic inflammation, including atopic dermatitis.

\section{Acknowledgements \\ This study was supported by Technology Development Program for Agriculture and Forestry, Ministry for Food, Agriculture, Forestry and Fisheries, Republic of Korea.}

\section{Author details \\ ${ }^{1}$ Department of Herbal Medicine Resource, Kangwon National University, Samcheok, 245-711, Korea. ${ }^{2}$ College of Pharmacy, Sungkyunkwan University, Suwon, 440-746, Korea. ${ }^{3}$ Department of Natural Medicine Resources, Semyung University, Jecheon, 309-711, Korea. ${ }^{4}$ College of Pharmacy, Hanyang University, Ansan, 426-791, Korea. ${ }^{5}$ Department of Pediatrics, College of Medicine, Hanyang University, Seoul, 133-792, Korea.}

\section{Authors' contributions}

EHS carried out the molecular genetic studies, and drafted the manuscript. SAJ, SP, carried out the immunoassays and western blotting. HJ carried out the RT-PCR and XTT assay. SCK participated in the design of the study and performed the statistical analysis. CHL and SYK conceived of the study, and participated in its design and coordination and helped to draft the manuscript. All authors read and approved the final manuscript.

\section{Competing interests}

The authors declare that they have no competing interests.

Received: 12 November 2010 Accepted: 8 February 2011 Published: 8 February 2011

\section{References}

1. Akdis CA, Akdis $M$, Trautmann A, Blaser $\mathrm{K}$ : Immune regulation in atopic dermatitis. Curr Opin Immunol 2000, 12:641-6.

2. Leung DY, Bieber T: Atopic dermatitis. Lancet 2003, 361:151-60.

3. Guo YC, Li ZX, Lin H: Investigation on the relationship among histamine, tryptase and beta-hexosaminidase in the process of mast cell degranulation. Xi Bao Yu Fen Zi Mian Yi Xue Za Zhi 2009, 25:1073-5.

4. Church MK, Levi-Schaffer F: The human mast cell. J Allergy Clin Immunol 1997, 99:155-60.

5. Gilfillan AM, Tkaczyk C: Integrated signalling pathways for mast-cell activation. Nat Rev Immunol 2006, 6:218-30.

6. Homey B, Steinhoff M, Ruzicka T, Leung DY: Cytokines and chemokines orchestrate atopic skin inflammation. J Allergy Clin Immunol 2006, 118:178-89.

7. Georas SN, Guo J, De Fanis U, Casolaro V: T-helper cell type-2 regulation in allergic disease. Eur Respir J 2005, 26:1119-37.

8. Park SY, Hong SS, Han X, Hwang JS, Lee D, Ro JS, Hwang BY: Lignans from Arctium lappa and their inhibition of LPS-induced nitric oxide production. Chem Pharm Bull 2007, 55:150-2.

9. Lin CC, Lu JM, Yang JJ, Chuang SC, Ujiie T: Anti-inflammatory and radical scavenge effects of Arctium lappa. Am J Chin Med 1996, 24:127-37.

10. Chen $F A, W u A B$, Chen $C Y$ : The influence of different treatment on the free radical scavenging activity of burdock and variations of its active components. Food Chem 2004, 86:479-84.

11. Maruta $Y$, Kawabata J, Niki R: Antioxidative caffeoylquinic acid derivatives in the roots of burdock (Arctium lappa L.). J Agric Food Chem 1995, 43:2592-5

12. Fuchigami M, Kishigami $Y$, Sasaki A: Pectic polysaccharides in edible burdock root. Journal of Home Economics Japan 1990, 41:947-62.

13. Morita KY, Nishijima Y, Kada T: Chemical nature of a desmutagenic factor from burdock (Arctium lappa Linne). Agric Biol Chem 1985, 49:925-32.

14. Lin SC, Lin CH, Lin CC, Lin YH, Chen CF, Chen IC, Wang LY: Hepatoprotective effects of Arctium lappa Linne on liver injuries induced by chronic ethanol consumption and potentiated by carbon tetrachloride tetrachloride. J Biomed Sci 2002, 9:401-9.

15. Theoharides TC, Kalogeromitros D: The critical role of mast cells in allergy and inflammation. Ann NY Acad Sci 2006, 1088:78-99.

16. Soter NA: Morphology of atopic eczema. Allergy 1989, 44(Suppl 9):16-9.

17. Grewe M, Walther S, Gyufko K, Czech W, Schöpf E, Krutmann : Analysis of the cytokine pattern expressed in situ in inhalant allergen patch test reactions of atopic dermatitis patients. J Invest Dermatol 1995, 105:407-10.

18. Grewe M, Bruijnzeel-Koomen CA, Schöpf E, Thepen T, LangeveldWildschut AG, Ruzicka T: A role for Th1 and Th2 cells in the immunopathogenesis of atopic dermatitis. Immunol Today 1998, 19:359-61.

19. Rothenberg ME, Luster AD, Leder P: Murine exotoxin: an eosinophil chemoattractant inducible in endothelial cells and in interleukin 4induced tumor suppression. Proc Natl Acad Sci USA 1995, 92:8960-4.

20. Kuhn R, Rajewsky K, Muller W: Generation and analysis of interleukin-4 deficient mice. Science 1991, 254:707-10.

21. Hines C: The diverse effects of mast cell mediators. Clin Rev Allergy Immunol 2002, 22:149-60.

22. Huels C, Germann T, Goedert S, Hoehn P, Koelsch S, Hültner L, Palm N, Rüde $E$, Schmitt E: Co-activation of naive CD4+ T cells and bone marrow derived mast cells results in the development of Th2 cells. Int Immunol 1995, 7:525-32.

23. Matsuda H, Watanabe N, Geba GP, Sperl J, Tsudzuki M, Hiroi J, Matsumoto M, Ushio H, Saito S, Askenase PW, Ra C: Development of atopic dermatitis-like skin lesion with IgE hyperproduction in NC/Nga mice. Int Immunol 1997, 9:461-6.

24. Karin M, Lin A: NF-KB at the crossroads of life and death. Nat Immunol 2002, 3:221-7.

25. Barnes PJ: Role of GATA-3 in allergic diseases. Curr Mol Med 2008, 8:330-4 
26. Yang L, Cohn L, Zhang DH, Homer R, Ray A, Ray P: Essential role of nuclear factor $B$ in the induction of eosinophilia in allergic airway inflammation. J Exp Med 1998, 188:1739-50.

doi:10.1186/1476-7961-9-4

Cite this article as: Sohn et al:: Anti-allergic and anti-inflammatory effects of butanol extract from Arctium Lappa L. Clinical and Molecular Allergy 2011 9:4.

Submit your next manuscript to BioMed Central and take full advantage of:

- Convenient online submission

- Thorough peer review

- No space constraints or color figure charges

- Immediate publication on acceptance

- Inclusion in PubMed, CAS, Scopus and Google Scholar

- Research which is freely available for redistribution 